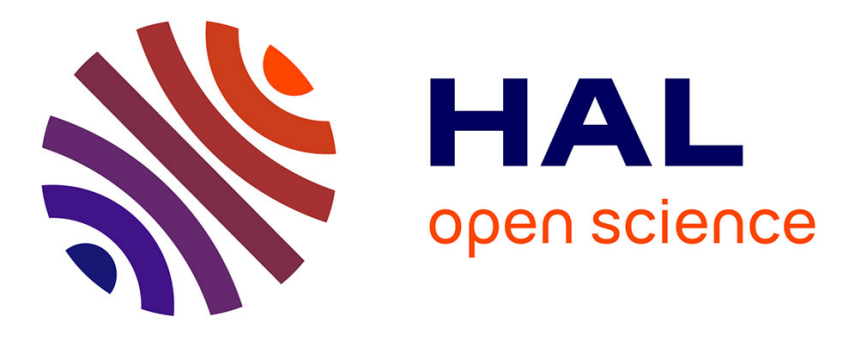

\title{
Biocontrol of sheath blight by Trichoderma asperellum in tropical lowland rice
}

\author{
Suenny Kelly Santos de França, Aline Figueiredo Cardoso, Denise Castro \\ Lustosa, Edson Marcos Leal Soares Ramos, Marta Cristina Corsi de Filippi, \\ Gisele Barata da Silva
}

\section{To cite this version:}

Suenny Kelly Santos de França, Aline Figueiredo Cardoso, Denise Castro Lustosa, Edson Marcos Leal Soares Ramos, Marta Cristina Corsi de Filippi, et al.. Biocontrol of sheath blight by Trichoderma asperellum in tropical lowland rice. Agronomy for Sustainable Development, 2015, 35 (1), pp.317-324. 10.1007/s13593-014-0244-3 . hal-01284265

\section{HAL Id: hal-01284265 https://hal.science/hal-01284265}

Submitted on 7 Mar 2016

HAL is a multi-disciplinary open access archive for the deposit and dissemination of scientific research documents, whether they are published or not. The documents may come from teaching and research institutions in France or abroad, or from public or private research centers.
L'archive ouverte pluridisciplinaire $\mathbf{H A L}$, est destinée au dépôt et à la diffusion de documents scientifiques de niveau recherche, publiés ou non, émanant des établissements d'enseignement et de recherche français ou étrangers, des laboratoires publics ou privés. 


\title{
Biocontrol of sheath blight by Trichoderma asperellum in tropical lowland rice
}

\author{
Suenny Kelly Santos de França • Aline Figueiredo Cardoso • Denise Castro Lustosa • \\ Edson Marcos Leal Soares Ramos • Marta Cristina Corsi de Filippi • Gisele Barata da Silva
}

Accepted: 22 July 2014 / Published online: 26 August 2014

(C) INRA and Springer-Verlag France 2014

\begin{abstract}
Crop damage by rice sheath blight, Rhizoctonia solani, can decrease rice yield by up to $45 \%$. The classical control method of rice sheath blight in the Amazon region is the application of fungicides. Therefore, we tested here the efficiency of a biocontrol agent, Trichoderma asperellum, and fungicides. Two experiments of rice cultivation were carried out with seven treatments: four isolates of T. asperellum, a mixture of the four isolates, the fungicide pencycuron, and the control. The first experiment involved a randomized block design, and seed and foliar spray on all plots. The second experiment involved a split-plot design with foliar spray in main plots and the 1-2 foliar sprays in subplots. Results show that all treatments reduced sheath blight progression rate. In the randomized block experiment $T$. asperellum reduced disease severity by $19 \%$, increased grain weight by $34 \%$, and increased yield by $41 \%$. In the split-plot design experiment, the mixture of the four T. asperellum isolates grain reduced disease
\end{abstract}

\footnotetext{
S. K. S. de França • A. F. Cardoso • G. B. da Silva $(\bowtie)$

Plant Protection Laboratory, Federal Rural University of Amazon, Av

Perimetral, 2501, 66077-901 Campus Belém, Pará, Brazil

e-mail: gibarata@bol.com.br

D. C. Lustosa

Federal Rural University of Western Para/IBF, Vera Paz, Sales, 68035-110 Santarém, PA, Brazil

e-mail: deniselustosa@yahoo.com.br

E. M. L. S. Ramos

Federal Rural University of Pará/Exact and Natural Science Center/ ICEN, Rua Augusto Corrêa, 01, 66075-110. CP 479 Belém, Pa, Brazil

e-mail: ramos.edson@gmail.com

M. C. C. de Filippi $(\bowtie)$

Plant Pathology Laboratory (Laboratório de Fitopatologia), Rice and Beans Research Center/EMBRAPA, Goiânia, Goiás, Brazil 75375-000

e-mail: cristina.filippi@embrapa.br
}

severity by $26 \%$, increased grain weight by $18.5 \%$, and increased yield by $26 \%$. Our results show for the first time that a mixed isolates of $T$. asperellum was efficient in reducing disease severity and increasing yield and grain weight.

Keywords Oryza sativa $\cdot$ Biological control $\cdot$ Field conditions $\cdot$ Amazon region $\cdot$ Rhizoctonia solani

\section{Introduction}

Rice sheath blight (Rhizoctonia solani JG Kühn) [teleomorph Thanatephorus cucumeris (Frank) Donk] causes damage to rice crops in the various regions of the world where rice is grown. Crop damage from rice sheath blight can result in a loss of production of up to $45 \%$, depending on the plant growth stage the disease onset and under favorable conditions around the world (Kumar et al. 2009). Brazil is among the top ten world producers of rice and has environmental conditions that are favorable to the development of sheath blight (Fig. 1). Tropical environmental conditions, inadequate crop management, and the susceptibility of the cultivars grown favor the high severity of this disease (Zheng et al. 2013). Although extensive evaluation of rice germplasm has been conducted for developing rice cultivars that are genetically resistant to sheath blight, there are still no cultivars with a significant degree of resistance (Srinivasachary et al. 2013). In the Amazon region, irrigated rice is cultivated by small farmers in areas along river banks. The fields are periodically flooded under the influence of river tides, and crops are grown in the highly fertile alluvial soils without the application of fertilizers. Despite these ideal conditions, continuous cultivation of these areas results in deterioration of the natural fertility of the soil, especially decreases in phosphorous, and also results in an increase in the $R$. solani inoculum. Until now, sheath blight control strategies have relied mainly on fungicides. 

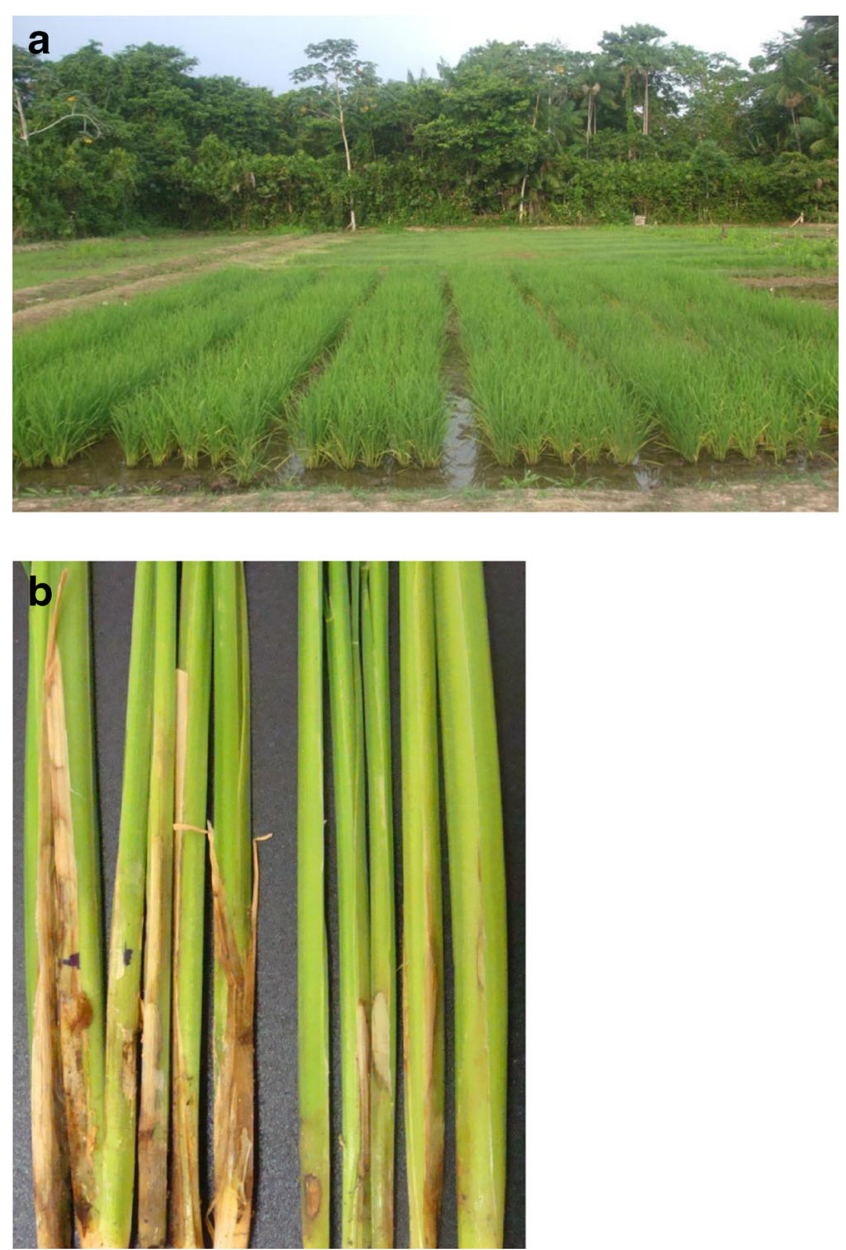

Fig. 1 Irrigated rice field experiment under tropical environmental conditions, favorable to sheath blight development (a). Rhizoctonia solani damage on untreated rice plants (left) or treated with Trichoderma asperellum, under field conditions (b)

The genus Trichoderma (Hypocreales, Ascomycota) is known for its antagonistic activity against several plant pathogens, including $R$. solani (Harman 2006). There are many studies reporting that biological control with Trichoderma may be effective in minimizing the incidence of sheath blight in rice (Das and Hazarika 2000; Tewari and Singh 2005; Naeimi et al. 2010). However, most of them were performed in vitro and in the greenhouse (Naeimi et al. 2010) and only few reported efficiency under field conditions considering method of application in the plant (foliar spray or treatment of seed) and formulation. The main objective of this study was to develop an effective method of applying Trichoderma spp. for controlling sheath blight in rice under flooded conditions.

\section{Materials and methods}

Two experiments were conducted on the Rio Guamá flood plain, in Belem, Pará State, Brazil. Each experiment used a distinct planting system. Experiment 1 used a sowing system with two distinct and consecutive planting times and was conducted during the November 2010 crop season. Experiment 2 used a transplanting system with two distinct and consecutive planting times and was conducted during the December 2011 crop season.

\subsection{The pathogen (R. solani) and the biological agent (Trichoderma asperellum)}

The pathogen inoculum consisted of 2-cm long toothpick segments that were sterilized for $20 \mathrm{~min}$ at $120^{\circ} \mathrm{C}$ and placed in Petri plates containing a potato dextrose agar (PDA) medium colonized by $R$. solani (4F1, AG1 IA anastomosis group, Embrapa Rice and Beans microorganism collection).

The biological agents used were isolates of T. asperellum (T.06, T.09, T.12, and T.52), which were isolated from rhizospheric soils of reforested and native forest areas in the Amazon. Prior to the experiment, these strains were assessed and identified in vitro and through greenhouse studies by the Federal Rural University of Amazonia (UFRA) Plant Protection Laboratory. The T. asperellum isolates were grown in Petri dishes containing BDA for 5 days and bioformulated as described by Silva et al. (2012).

\subsection{Sowing system experiment (experiment 1)}

The experiment occupied a field area of $287.55 \mathrm{~m}^{2}$ and consisted of two trials planted consecutively during the 2011/2012 season. The minimum temperature was $23.2^{\circ} \mathrm{C}$ and the maximum temperature was $33.7^{\circ} \mathrm{C}$. Relative humidity ranged from 69 to $100 \%$, and rainfall levels ranged from 136.2 to $520.3 \mathrm{~mm}$ (INMET 2012) during the season. The field was prepared by mechanically incorporating crop debris. The experimental design was a randomized block with four replications, consisting of two trials with consecutive planting dates performed during a single season. Each plot had seven 2.5-m long rows spaced $0.2-\mathrm{m}$ apart, with 80 seeds planted per meter. Prior to planting, seeds of the rice cultivar BRS Tropical were sterilized in alcohol (70 \%) and hypochlorite (2\%) and rinsed in water.

\subsubsection{Experiment 1 treatments}

The treatments included five seed treatments (ST) with the biological agent $T$. asperellum isolate $(\mathrm{T} 1=\mathrm{T} .06, \mathrm{~T} 2=\mathrm{T} .09$, $\mathrm{T} 3=\mathrm{T} .12, \mathrm{~T} 4=\mathrm{T} .52$, and $\mathrm{T} 5=\mathrm{mix}$ of four isolates), a fungicide treatment $(\mathrm{T} 6=$ pencycuron), and a control $(\mathrm{T} 7=$ water). Following the seed treatment, the plants were treated twice by foliar spraying with the same isolate or product used in seed treatment. The first spray, at 57 days after sowing (DAS), was considered preventive, and the second spray, at 66 DAS, was considered curative. The biocontrol seed treatments were 
performed at concentrations of $10 \mathrm{~g}$ of powdered T. asperellum per $1 \mathrm{~kg}$ of seed and $250 \mathrm{~g}_{\text {ai kg }}{ }^{-1}$ of pencycuron per $1 \mathrm{~kg}$ of seed. For all treatments, the foliar sprays were performed with an SS $5 \mathrm{~L}$ backpack sprayer at a pressure of $7-12.6 \mathrm{kgfcm}^{-2}$ and a spray volume of $500 \mathrm{~L} \mathrm{ha}^{-1}$. The concentration of the biological solutions was $10^{8}$ conidia per milliliter and the chemical fungicide concentration was $250 \mathrm{~g}$ ai $\mathrm{L}^{-1}$. The control treatment group was sprayed with water only.

\subsubsection{Experiment 1 inoculation procedure}

The toothpick segments colonized with $R$. solani were inserted between the flag leaf sheath and plant culm of the marked main tillers located along the central line of each plot. The plants were inoculated at 62 days after sowing (DAS), which was 5 days after the first foliar spray (57 DAS) and 5 days before the second foliar spray (66 DAS).

\subsection{Transplanting system experiment (experiment 2)}

The experiment occupied $296.84 \mathrm{~m}^{2}$ and consisted of two trials planted consecutively during the 2011/2012 season.

\subsubsection{Seedling production and transplantation}

Seeds of rice cultivar BRS Tropical were sown on $1.5 \times 20 \mathrm{~m}$ plots. When the seedlings were 30 days old and $15 \mathrm{~cm}$ in height, two to three seedlings were transplanted to the experimental plots, which were fertilized with $20 \mathrm{~g}$ of NPK (11-23$20+$ S) per crop row. Minimum temperatures ranged from 23.5 to $32{ }^{\circ} \mathrm{C}$, relative humidity ranged from 67 to $100 \%$, and rainfall ranged from 139.1 to $440 \mathrm{~mm}$ (INMET 2012). A randomized block design was used with three replications and seven treatments in a split-plot design. The plots consisted of six 5-m long rows with 2.5-long subplots, with the rows and furrows spaced at $0.2 \mathrm{~m}$.

\subsubsection{Experiment 2 treatments}

The treatments consisted of one or two foliar spray treatments with the biological agent $T$. asperellum isolate $(\mathrm{T} 1=\mathrm{T} .06, \mathrm{~T} 2=\mathrm{T} .09, \mathrm{~T} 3=\mathrm{T} .12, \mathrm{~T} 4=\mathrm{T} .52, \mathrm{~T} 5=\operatorname{mix}$ of four), a fungicide ( $\mathrm{T} 6=$ pencycuron), or a control $(\mathrm{T} 7=$ water). Each subplot was treated with either one or two foliar sprays. The first spray treatment was applied the first 20 days after transplanting (50 DAT) and was considered a preventive application. The second foliar spray was applied 30 days after transplanting (60 DAT) and was considered a curative application.

\subsubsection{Experiment 2 inoculation procedure}

R. solani was inoculated 25 days after transplanting (DAT) using the same methods described for the experiment 1 inoculation.

2.4 Experiments 1 and 2 sheath blight severity and yield assessment

For both experiments (experiments 1 and 2) disease severity, disease progression $(r)$ and a number of plant productivity parameters were assessed. In experiment 1 , disease severity was assessed at $64,66,67,69$, and 74 days after sowing (DAS). At 64 DAS, the plants had been treated with a preventive spray and inoculated with $R$. solani. At 66 DAS and the other evaluation dates thereafter, the plants had been treated with both sprays (preventive and curative) and inoculated with $R$. solani. In experiment 2 , disease severity was assessed at 57, 59, 62, 64, and 66 days after sowing (DAS). At 57 and 59 DAS, the plants had been treated with the preventive spray and inoculated with $R$. solani. On the remaining evaluation dates, the plants had been treated with both sprays (preventive and curative) and inoculated with $R$. solani. Severity of sheath blight was based on vertical lesion length, which was measured on 20 main tillers per repetition and evaluated for 5 days at intervals of 1 to 5 days. Yield parameters included panicle length $(\mathrm{cm})$ and mass $(\mathrm{g})$, grain weight (g) and weight of 100 grains $(\mathrm{g})$, and yield $\left(\mathrm{kg} \mathrm{ha}^{-1}\right)$ measured along the central row of each plot.

Area under disease progress curve (AUDPC) was calculated using the disease severity data according to Shanner and Finney (1977). Disease progression rate $(r)$ was determined by linear regression. The parameter $b$ of the model equation was obtained from the model that was the best fit for the data. The empirical models tested included: logistic $Y=1 / 1+$ $\exp (-(\beta+r \times t))$; monomolecular $Y=1-\left(1-y_{0} \times\right.$ $\exp (-r \times t)$; and Gompertz $Y=\exp \left(-\left(-\ln \left(y_{0}\right)\right) \times\right.$ exp $(-r \times t))$ according to Campbell and Madden (1990). For each experiment, the best model was selected based on a high $R^{2}$ value, a low mean square value, and a plot of standardized residuals $\left(y_{\text {obs }}-y_{\text {exp }}\right)$ that did not show trends or values close to the $x$-axis (data not shown).

\section{Results and discussion}

\subsection{Epidemic sheath blight}

The statistical analysis showed that there was no difference between the two trials in either in experiment 1 or 2 , indicating that the treatments had the same effect regardless of planting date. In both trials of experiments 1 and 2, all treatments 
reduced sheath blight severity, AUDPC and the sheath blight progression rate $(r)$ compared to those of the control (Fig. 2). Among the T. asperellum isolates, T.06 was associated with the lowest AUDPC and differed statistically only from the T.09 isolate (Fig. 2). The T. asperellum and fungicide treatments reduced the disease progression rate compared to those of the control. However, there were no differences in disease progression rate among the $T$. asperellum isolates or the fungicide, with $r$ ranging from 0.62 to 0.76 in experiment 1 and from 0.54 to 0.61 in experiment 2 . The disease progression rate was best explained by the logistic model $Y=1 / 1+$ $\exp (-(\beta+r \times t))$, where $Y$ is the ratio of disease severity expressed as a percentage, $\beta$ the integration constant, $r$ is the disease progression rate, and $t$ is the time in days (Campbell and Madden 1990). For both experiments, the selection of this model was based on a higher $R^{2}$ value, a lower mean square value and a plot of the standardized residuals $\left(y_{\text {obs }}-y_{\text {exp }}\right)$ that did show any trends or values close to the $x$-axis (data not shown).

There was no significant difference between the fungicide and the isolates of $T$. asperellum concerning sheath blight severity, in all dates assessed, in experiment 2 trials. Additionally, no significant difference was observed among fungicide,
T.52 and mixed-isolate for AUDPC; however, for the same parameter, the fungicide pencycuron statistically differed from T.09 and T.06.

\subsection{Yield}

Rice yield parameters differed among the treatments in experiment 1, except for number of grains per panicle (Table 1). Except for T.52, all treatments were associated with a panicle length that was higher than that of the control. The mixedisolate treatment showed relatively higher values than the other treatments for grain mass/panicle, 100-grain weight, and productivity. The correlations between AUDPC and the yield parameters were negative (Table 2) for all evaluated parameters. The only statistically significant correlations with AUDPC were for panicle length $(r=-0.298)$, grain weight $(r=$ $-0.317)$, and yield ( $r=-0.317)$. In experiment 2 , all treatments improved yield and yield parameters (Table 1). Panicle weight and length and grain weight/panicle were statistically higher for all treatments compared to those of the control. The fungicide treatment was associated with the highest 100grain mass, followed by the T.09, T.52, and mixed-isolate treatments. In all treatments, 100-grain mass was statistically
Fig. 2 Area under the disease progress curve (AUDPC) for rice plants treated with the biocontrol agent Trichoderma asperellum and the fungicide pencycuron in a tropical lowland environment, Belém, PA, November 2010 (experiment 1). Treatments consisted of seed treatment + one preventative spray + one curative spray (experiment 2). Treatments consisted of one preventative spray + one curative spray days after sowing

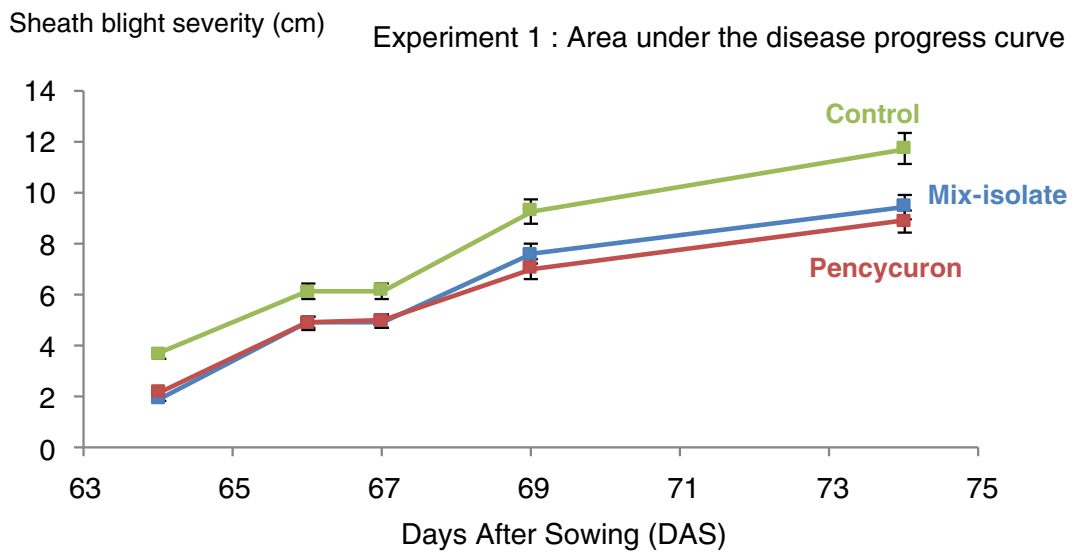

Sheath blight severity $(\mathrm{cm}) \quad$ Experiment 2 : Area under the disease progress curve

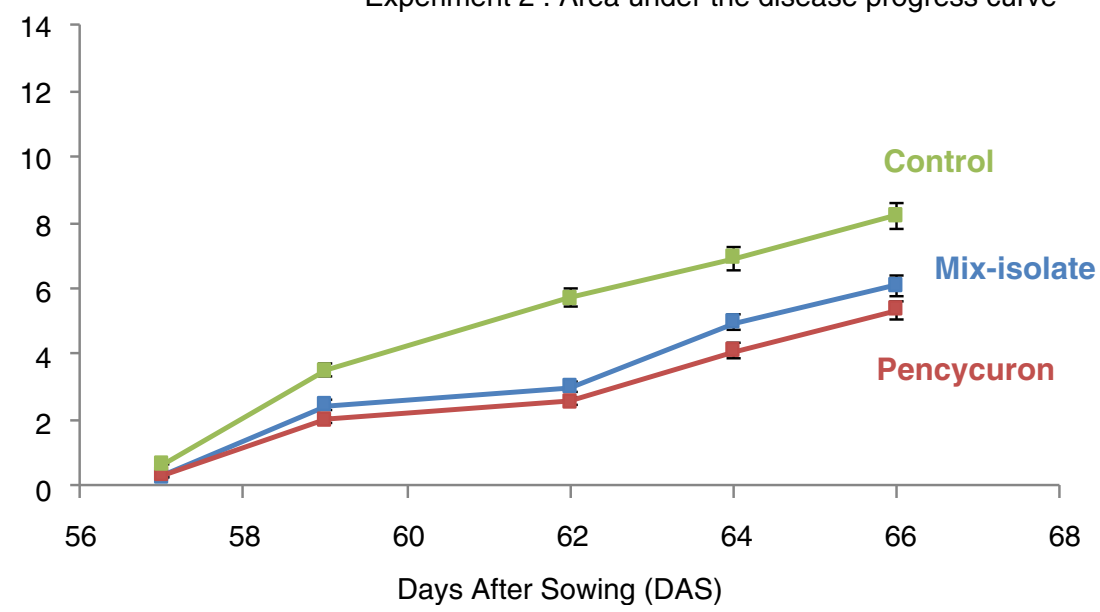


Table 1 Yield parameters from the sowing system experiment (experiment 1: November 2010) and transplanting system experiment (experiment 2: December 2011) for treatments with isolates of Trichoderma asperellum and the fungicide pencycuron for the control of sheath blight in rice in tropical lowland environments

\begin{tabular}{|c|c|c|c|c|c|}
\hline \multirow[t]{2}{*}{ Treatment $\mathrm{t}^{\mathrm{a}}$} & \multicolumn{3}{|l|}{ Panicle } & \multirow[t]{2}{*}{ 100-grain mass (g) } & \multirow[t]{2}{*}{ Yield $\left(\mathrm{kg} \mathrm{ha}^{-1}\right)$} \\
\hline & Length (cm) & Grain number & Grain mass (g) & & \\
\hline \multicolumn{6}{|c|}{ Sowing system ${ }^{\mathrm{b}}$ (E1) } \\
\hline T.06 & $21.58 \pm 0.24 b c^{c}$ & $102.07 \pm 3.35 \mathrm{a}$ & $2.37 \pm 0.17 b c$ & $2.30 \pm 0.12 b$ & $3.238 .63 \mathrm{ab}$ \\
\hline Т.09 & $22.60 \pm 0.62 \mathrm{abc}$ & $95.30 \pm 7.43 \mathrm{a}$ & $2.23 \pm 0.15 b c$ & $2.37 \pm 0.12 b$ & $3.428 .44 \mathrm{ab}$ \\
\hline T.12 & $22.81 \pm 0.63 \mathrm{abc}$ & $108.11 \pm 6.85 \mathrm{a}$ & $2.24 \pm 0.17 b c$ & $2.06 \pm 0.06 \mathrm{~b}$ & $3.498 .68 \mathrm{ab}$ \\
\hline T.52 & $21.20 \pm 0.36 \mathrm{c}$ & $93.48 \pm 7.51 \mathrm{a}$ & $2.16 \pm 0.13 b c$ & $2.35 \pm 0.15 b$ & $3.045 .64 b$ \\
\hline Mix & $24.07 \pm 1.23 \mathrm{a}$ & $101.10 \pm 9.51 \mathrm{a}$ & $2.97 \pm 0.17 \mathrm{a}$ & $3.12 \pm 0.34 \mathrm{a}$ & $4.377 .51 \mathrm{a}$ \\
\hline Pencycuron & $23.52 \pm 0.33 \mathrm{ab}$ & $107.83 \pm 10.60 \mathrm{a}$ & $2.55 \pm 0.18 \mathrm{ab}$ & $2.49 \pm 0.25 b$ & $3.026 .32 \mathrm{~b}$ \\
\hline Control & $21.36 \pm 0.34 \mathrm{c}$ & $98.38 \pm 5.12 \mathrm{a}$ & $2.03 \pm 0.13 \mathrm{c}$ & $2.05 \pm 0.08 \mathrm{~b}$ & $2.565 .61 \mathrm{c}$ \\
\hline CV (\%) & 8.72 & 20.65 & 21.68 & 24.81 & 38.64 \\
\hline \multicolumn{6}{|c|}{ Transplanting system ${ }^{\mathrm{d}}$ (E2) } \\
\hline T.06 & $23.38 \pm 0.21 \mathrm{a}$ & $4.27 \pm 0.14 \mathrm{a}$ & $3.54 \pm 0.08 \mathrm{a}$ & $2.61 \pm 0.06 \mathrm{~b}$ & $2.794 .05 \mathrm{a}$ \\
\hline Т.09 & $23.58 \pm 0.22 \mathrm{a}$ & $4.35 \pm 0.19 \mathrm{a}$ & $3.58 \pm 0.14 \mathrm{a}$ & $2.67 \pm 0.05 \mathrm{ab}$ & $2.858 .09 \mathrm{a}$ \\
\hline T.12 & $23.70 \pm 0.32 \mathrm{a}$ & $4.33 \pm 0.21 \mathrm{a}$ & $3.46 \pm 0.11 \mathrm{a}$ & $2.58 \pm 0.06 \mathrm{~b}$ & $2.748 .40 \mathrm{a}$ \\
\hline T.52 & $23.73 \pm 0.25 \mathrm{a}$ & $4.41 \pm 0.16 \mathrm{a}$ & $3.63 \pm 0.12 \mathrm{a}$ & $2.63 \pm 0.08 \mathrm{ab}$ & $2.818 .35 \mathrm{a}$ \\
\hline Mix & $23.93 \pm 0.15 \mathrm{a}$ & $4.63 \pm 0.18 \mathrm{a}$ & $3.88 \pm 0.11 \mathrm{a}$ & $2.65 \pm 0.07 \mathrm{ab}$ & $2.882 .87 \mathrm{a}$ \\
\hline Pencycuron & $23.58 \pm 0.26 \mathrm{a}$ & $4.69 \pm 0.26 \mathrm{a}$ & $4.01 \pm 0.20 \mathrm{a}$ & $2.92 \pm 0.21 \mathrm{a}$ & $3.092 .18 \mathrm{a}$ \\
\hline Control & $21.48 \pm 0.27 b$ & $3.35 \pm 0.22 b$ & $2.78 \pm 0.19 b$ & $2.16 \pm 0.04 \mathrm{c}$ & $2.135 .08 \mathrm{~b}$ \\
\hline $\mathrm{CV}(\%)$ & 4.84 & 18.09 & 16.69 & 14.81 & 16.82 \\
\hline
\end{tabular}

$\mathrm{CV}$ coefficient of variation

${ }^{\mathrm{a}}$ T.06, T.09, T.12, and T.52 = T. asperellum isolates; $\mathrm{mix}=$ combination of four T. asperellum isolates; pencycuron (fungicide); control = water

${ }^{\mathrm{b}}$ Sowing system experiment (experiment 1$)$ : seed treatment + one preventative spray + one curative spray $(n=8)$

${ }^{\mathrm{c}}$ Data [mean \pm standard error] followed by the same letter in the column do not differ by a Duncan test $(P<0.05)$

${ }^{\mathrm{d}}$ Transplanting system experiment (experiment 2$)$ : one preventative spray+one curative spray $(n=12)$

Table 2 Correlation coefficients for sheath blight and yield parameters in a sowing system experiment (experiment 1) and transplanting system experiment (experiment 2) with rice treated with isolates of Trichoderma asperellum in a tropical lowland environment

\begin{tabular}{|c|c|c|c|c|c|}
\hline Parameter & Length & Number & Mass & 100-grain mass & Yield \\
\hline \multicolumn{6}{|l|}{ Sowing system (E1) } \\
\hline AUDPC & $-0.298^{*}$ & -0.141 & $-0.317^{*}$ & -0.214 & $-0.297^{*}$ \\
\hline Panicle length $(\mathrm{cm})$ & - & 0.205 & $0.488 * *$ & $0.358 * *$ & $0.274 *$ \\
\hline Number (grain number/panicle) & & - & $0.504 * *$ & $-0.430 * *$ & -0.114 \\
\hline Grain mass (g) & & & - & $0.550 * *$ & 0.194 \\
\hline 100-grain mass (g) & & & & - & $0.305^{*}$ \\
\hline Yield $\left(\mathrm{kg} \mathrm{ha}^{-1}\right)$ & & & & & - \\
\hline \multicolumn{6}{|l|}{ Transplanting system (E2) } \\
\hline AUDPC & $-0.288 * *$ & $-0.475^{* *}$ & $-0.381 * *$ & $-0.541 * *$ & $-0.371^{* *}$ \\
\hline Panicle length $(\mathrm{cm})$ & - & $0.379 * *$ & $0.547 * *$ & 0.185 & $0.501^{* *}$ \\
\hline Number (grain number/panicle) & & - & $0.841 * *$ & $0.584 * *$ & $0.305^{* *}$ \\
\hline Grain mass (g) & & & - & $0.568 * *$ & $0.448^{* *}$ \\
\hline 100-grain mass (g) & & & & - & $0.229 *$ \\
\hline Yield $\left(\mathrm{kg} \mathrm{ha}^{-1}\right)$ & & & & & - \\
\hline
\end{tabular}

$A U D P C$ area under disease progress curve

${ }^{*} P<0.05 ; * * P<0.01 ; n=84$ 
higher than in the control. AUDPC was statistically correlated with all yield parameters (Table 2).

$R$. solani is a plant pathogen with strong saprophytic abilities that forms sclerotia in the soil, and the availability of pesticides that control this pathogen is very low (Prabhu et al. 2002; Naeimi et al. 2010). Successful biological control of sheath blight by the bioagent Trichoderma has been recorded by several authors, mostly in greenhouse studies, with few studies conducted under field conditions (Krishnamurthy et al. 1999; Mathivanan et al. 2005; Silva et al. 2012). Our results showed that $T$. asperellum isolates suppressed sheath blight, promoted planted growth, and increased plant yields under tropical lowland field conditions. Seed treatment with T. asperellum followed by a single foliar spraying reduced sheath blight severity by $36 \%$ (measured at $64 \mathrm{DAS}$ ), and seed treatment with $T$. asperellum followed by two foliar sprays reduced sheath blight severity by $21 \%$ at the end of the epidemic (scored at 74 DAS). In experiment 2, sheath blight was reduced by $27 \%$ at 66 DAS in transplants that were sprayed only once with $T$. asperellum. However, there were no significant differences in disease severity if plants were sprayed once or twice in experiment 2 (data not shown). In both experiments, treatments where fungicide was sprayed, sheath blight severity was lower by 25 and $35 \%$, respectively, when compared to that of the control. Silva et al. (2012) reported antibiosis by mycoparasitism and toxic compounds production for the same four T. asperellum isolates (T.06, T.09, T.12, T.52) used in this study on $R$. solani. We attribute the success of $T$. asperellum in suppressing sheath blight severity under field conditions to the same mechanisms described by Silva et al. (2012). Abdel-Fattah et al. (2007) found that applications of Trichoderma harzianum sprayed at 15-day intervals reduced the severity of brown spot on rice leaves grown in a field. The author noted that Trichoderma spp. can induce systemic and localized resistance by the plant and form an antagonistic relationship with the pathogen by directly attacking the pathogen or inhibiting pathogen growth and colonization of the plant. Even though we observed that seed treatment (experiments 1 and 2) reduced sheath blight severity and increased plant yields, it was not possible to confirm mechanisms of local or systemic resistance. However, we will seek evidence of this mechanism in future experiments. Although sheath blight is caused by a resident soil pathogen, it showed polycyclic behavior, evidenced by rapid disease development within the same host cycle.

Seven days after pathogen inoculation, sheath blight severity increased 44 and $76 \%$ in experiments 1 and 2, respectively. Based on the control treatment, it was observed that the daily growth rate of disease severity was $0.8 \mathrm{~cm}$, in both experiments. We believe that the rapid development of sheath blight was due to the aggressiveness of the pathogen and the favorable tropical lowland environmental conditions, such as high temperature and humidity. Based on the epidemiological parameters we measured, AUDPC and $r$, a logistic model best explained sheath blight development (based on the high $R^{2}$ value, low mean square value, and plot of standardized residuals in both experiments). We found decreases in AUCPD of 22 and $34 \%$ for plants sprayed with $T$. asperellum in experiments 1 and 2, respectively. Based on the values for disease progression rate of 28 and $17 \%$ in experiment 1 and 2, respectively, T. asperellum reduced the increment of daily progression of the disease.

Disease severity and AUCPD were higher in experiment 1 compared to those in 2 , in which was combined seed treatment and foliar spray with Trichoderma. This result is similar to those reported by Tewari and Singh (2005) and Naeimi et al. (2010) that a spore suspension sprayed on the leaves significantly reduced sheath blight severity and was more effective than soil treatment or seedling root dip. However, these studies were conducted in greenhouse conditions, with no seed treatment combined with spore suspension sprayed on the leaves and yield was not evaluate.

In the presented study, sheath blight negatively affected all yield parameters (Table 2). Although the plants treated with T. asperellum presented an increase in yield in both experiments, the best treatment for reducing disease severity has not provided the greatest productivity gain. In experiment 1 , plants treated with the mixed-isolate (combination of all four T. asperellum isolates) presented increases of $34 \%$ in 100 grain weight, $41 \%$ in yield, and $19 \%$ in disease severity reduction compared to those in the control. In contrast, in experiment 2 , the mixed-isolate treatment was associated with an increase of only $18.5 \%$ in 100 -grain mass and of $26 \%$ in yield and $26 \%$ in disease severity reduction. This result indicates that first of all, the combination of four T. asperellum isolates had a synergistic effect and the application method, seed treatment followed by foliar spray completed each other, allowing that the biological agent $T$. asperellum acted not only as a disease antagonist but also as a growth promoter.

Based on greenhouse and laboratory studies by Silva et al. (2012), it demonstrated that the application of the same four isolates of Trichoderma to rice plants, grown under greenhouse conditions, resulted in increased biomass, root length, and plant size, and reduced the severity of sheath blight. Among the known mechanisms involved in achieving these results was the production of phytohormones such as indoleacetic acid (IAA), the production of biomolecules involved in metabolic pathways that cause walling off of the Trichoderma thallus, phosphate solubilization, and induced systemic resistance.

The fungicide treatment also increased 100-grain weight and yield by 20 and $15 \%$, respectively, compared to that of the control, in experiment 1 . However, it presented $30 \%$ less in productivity when compared to the treatment composed of T. asperellum mixed-isolate. In contrast, in experiment 2 , although these two treatments were similar, fungicide 
treatment increased productivity in $30 \%$ when compared to that of the control (Table 2). Fungicide seed treatments provide protection only during the residual period. In this way, fungicides are different from biological agents, which provide protection for longer period during the process of germination and seedling growth because the agents colonize the host.

The benefits of Trichoderma spp. for plant growth and yield have been observed in greenhouse and field experiments, especially when certain isolates are used in combination (Harman et al. 2004; Hoyos-Carvajal et al. 2009). Reduced sheath blight and increased yields have been observed in rice (Mathivanan et al. 2005) and other crops (Raj et al. 2005; Saber et al. 2009; Tchameni et al. 2011), although the mechanisms involved mechanisms are not yet fully understood. There are many variables at play in the complex interactions between host-pathogen-antagonists under field conditions. Therefore, additional studies are needed to elucidate all the modes of action by which Trichoderma can reduce sheath blight and promote growth (Howell 2003; Harman 2006; Vinale et al. 2008).

\section{Conclusion}

We demonstrated that mixed isolates of T. asperellum combined on seed treatment and foliar spray was efficient on reducing disease severity and increasing yield and grain weight, in cultivated rice under flooded conditions. Considering all of the parameters evaluated in this study, the treatments that included the bioagent $T$. asperellum showed a level of efficiency that was similar to that of the fungicide pencycuron in both experiments. Trichoderma as a plant growth promoter could play an important role in maintaining sustainable rice production in the Amazon, by promoting increases in yield and reducing the contamination of the rivers, which sustain the floodplains used for household and large-scale production. To insert Trichoderma in the sheath blight integrated management, some studies will be necessary regarding the benefit cost, the establishment of a process for large-scale production, and official reports to enforcement of the law. Despite the long distance between scientific research and market, the demand for sustainable production systems and food quality by society will continues to push this kind of investigations.

\section{References}

Abdel-Fattah GM, Shaban YM, Ismail AE, Rashad YM (2007) Trichoderma harzianum: a biocontrol agent against Bipolaris oryzae. Mycopathologia 164:81-89. doi:10.1007/s11046-0079032-9
Campbell CL, Madden LV (1990) Introduction to plant disease epidemiology. John Wiley \& Sons, New York

Das BC, Hazarika DK (2000) Biological management of sheath blight of rice. Indian Phytopathol 53:433-435

Harman GE (2006) Overview of mechanisms and uses of Trichoderma spp. Phytopathology 96:190-194. doi:10.1094/ PHYTO-96-0190

Harman GE, Howell CR, Viterbo A, Chet I, Lorito M (2004) Trichoderma species - opportunistic, avirulent plant symbionts. Nat Rev Microbiol 2:43-56. doi:10.1038/nrmicro797

Howell CR (2003) Mechanisms employed by Trichoderma species in the biological control of plant diseases: the history and evolution of current concepts. Plant Dis 87:4-10. doi:10. 1094/PDIS.2003.87.1.4

Hoyos-Carvajal L, Orduz S, Bissett J (2009) Growth stimulation in bean (Phaseolus vulgaris L.) by Trichoderma. Biol Control 51:409-416. doi:10.1016/j.biocontrol.2009.07.018

Instituto Nacional de Meteorologia (INMET) (2012). (http://www.inmet. gov.br/portal/index.php?r=bdmep/bdmep). Accessed 29 February 2012

Krishnamurthy J, Samiyappan R, Vidhyasekaran P, Nakkeeran S, Rajeswari E, Raja JAJ, Balasubramanian P (1999) Efficacy of Trichoderma chitinases against Rhizoctonia solani the rice sheath blight pathogen. J Biosci 24:207-213. doi:10.1007/ BF02941202

Kumar KVK, Reddy MS, Kloepper JW, Lawrence KS, Groth DE, Miller ME (2009) Sheath blight disease of rice (Oryza sativa L.) - an overview. Biosci Biotechnol Res Asia 6:465-480

Mathivanan N, Prabavathy VR, Vijayanandraj VR (2005) Application of talc formulations of Pseudomonas fluorescens Migula and Trichoderma viride Pers. Ex S.F. gray decrease the sheath blight disease and enhance the plant growth and yield in rice. J Phytopathol 153:697-701

Naeimi S, Okhovvat SM, Javan-Nikkhah M, Vágvölgyi C, Khosravi V, Kredics L (2010) Biological control of Rhizoctonia solani AG1-1A, the causal agent of rice sheath blight with Trichoderma strains. Phytopathol Mediterr 49:287-300

Prabhu AS, Filippi MC, Silva GB, Santos GR (2002) Resistência de cultivares de arroz a Rhizoctonia solani e Rhizoctonia oryzae. Pesq Agropec Bras 37:589-595. doi:10.1590/S0100204X2002000500003

Raj SN, Shetty NP, Shetty HS (2005) Synergistic effects of Trichoshield on enhancement of growth and resistance to downy mildew in pearl millet. BioControl 50:493-509. doi:10.1007/ s10526-004-0460-x

Saber WIA, Abd El-hai KM, Ghoneem KM (2009) Synergistic effect of Trichoderma and Rhizobium on both biocontrol of chocolate spot disease and induction of nodulation. Physiological activities and productivity of Vicia faba. Res J Microbiol 4:286-300. doi:10. 3923/jm.2009.286.300

Shaner G, Finney RE (1977) The effect of nitrogen-fertilization on expression of slow-mildewing resistance in Knox wheat. Phytopathology 67:1051-1056

Silva JC, Torres DB, Lustosa DC, Filippi MCC, Silva GB (2012) Biocontrol of sheath blight on rice and growth promotion by Trichoderma isolates from the Amazon. Rev Ciênc Agrár 55:243250. doi:10.4322/rca.2012.078

Srinivasachary BG, Willocquet L, Savary S (2013) A strategy to identify sources of quantitative resistance in pathosystems involving disease escape and physiological resistance: the case study of rice sheath blight. Plant Pathol 62:888-899. doi:10.1111/j.1365-3059.2012. 02695.x

Tchameni SN, Ngonkeu MEL, Begoude BAD (2011) Effect of Trichoderma asperellum and arbuscular mycorrhizal fungi on cacao growth and resistance against black pod disease. Crop Prot 30: 1321-1327. doi:10.1016/j.cropro.2011.05.003 
Tewari L, Singh R (2005) Biological control of sheath blight of rice by Trichoderma harzianum using different delivery systems. Indian Phytopathol 58:35-40

Vinale F, Sivasithamparamb K, Ghisalbertic EL, Marraa R, Wooa SL, Lorito M (2008) Trichoderma-plant-pathogen interactions. Soil Biol Biochem 40:1-10. doi:10.1016/j.soilbio.2007.07.002
Zheng A, Lin R, Zhang D, Qin P, Xu L, Ai P, Ding L, Wang Y, Chen Y, Liu Y, Sun Z, Feng H, Liang X, Fu R, Tang C, Li Q, Zhang J, Xie Z, Deng Q, Li S, Wang S, Zhu J, Wang L, Liu $\mathrm{H}$, Li P (2013) The evolution and pathogenic mechanisms of the rice sheath blight pathogen. Nat Commun 4:1424. doi:10. $1038 /$ ncomms 2427 